\title{
Deferribacter thermophilus gen. nov., sp. nov., a Novel Thermophilic Manganese- and Iron-Reducing Bacterium Isolated from a Petroleum Reservoir
}

\author{
ANTHONY C. GREENE, ${ }^{*}$ BHARAT K. C. PATEL, ${ }^{2}$ AND ALAN J. SHEEHY ${ }^{1}$ \\ Microbiology Research Unit, Faculty of Applied Science, University of Canberra, Belconnen, Australian \\ Capital Territory 2616, ${ }^{1}$ and School of Biomolecular and Biomedical Sciences, Faculty of \\ Science and Technology, Griffith University, Nathan, Queensland $4111,{ }^{2}$ Australia
}

\begin{abstract}
A thermophilic anaerobic bacterium, designated strain $\mathbf{B M A}^{\mathbf{T}}(\mathrm{T}=$ type strain), was isolated from the production water of Beatrice oil field in the North Sea (United Kingdom). The cells were straight to bent rods ( 1 to 5 by 0.3 to $0.5 \mu \mathrm{m}$ ) which stained gram negative. Strain $\mathbf{B M A}^{\mathrm{T}}$ obtained energy from the reduction of manganese(IV), iron(III), and nitrate in the presence of yeast extract, peptone, Casamino Acids, tryptone, hydrogen, malate, acetate, citrate, pyruvate, lactate, succinate, and valerate. The isolate grew optimally at $60^{\circ} \mathrm{C}$ (temperature range for growth, 50 to $\left.65^{\circ} \mathrm{C}\right)$ and in the presence of $2 \%(\mathrm{wt} / \mathrm{vol}) \mathrm{NaCl}(\mathrm{NaCl}$ range for growth, 0 to $5 \%$ [wt/vol]). The DNA base composition was $34 \mathrm{~mol} \% \mathrm{G}+\mathrm{C}$. Phylogenetic analyses of the 16S rRNA gene indicated that strain $\mathrm{BMA}^{\mathrm{T}}$ is a member of the domain Bacteria. The closest known bacterium is the moderate thermophile Flexistipes sinusarabici (similarity value, $88 \%$ ). Strain $\mathrm{BMA}^{\mathrm{T}}$ possesses phenotypic and phylogenetic traits that do not allow its classification as a member of any previously described genus; therefore, we propose that this isolate should be described as a member of a novel species of a new genus, Deferribacter thermophilus gen. nov., sp. nov.
\end{abstract}

Metal-reducing microorganisms play important roles in the cycling of metals and organic matter, and iron- and manganese-reducing microorganisms are believed to be responsible for a substantial amount of carbon oxidation in marine sediments and other anaerobic environments $(16,17,25)$.

Dissimilatory manganese- and iron-reducing microorganisms which can couple $\mathrm{Mn}(\mathrm{IV})$ and/or Fe(III) reduction to the oxidation of carbon compounds have been isolated from sediments and extreme environments, such as the deep subsurface $(3,17,25)$. The isolates include strictly anaerobic bacteria belonging to the family Geobacteraceae (15), Bacillus infernus (3) and Geovibrio ferrireducens (6) strains, and facultatively anaerobic bacteria belonging to the genus Shewanella $(23,28)$. Nearly all of the known manganese- and iron-reducing isolates are mesophiles. While thermophilic iron reduction has been found in sediment samples from thermal springs (30), the only pure culture of a thermophilic iron reducer that has been described is a culture of $B$. infernus, an anaerobe from a deep terrestrial subsurface environment.

Petroleum reservoirs are frequently deep subsurface extreme environments having high temperatures, pressures, and levels of salinity, and several physiological groups of anaerobic bacteria, including thermophilic fermentative, sulfate-reducing, sulfur-reducing, and methanogenic microorganisms, have been isolated from these environments $(7,8,12,13,26,27,32)$. Mesophilic iron-reducing bacteria have been detected in oil field fluids $(24,29)$ and have been identified as Shewanella putrefaciens (29). The presence of thermophilic metal-reducing microorganisms in petroleum reservoirs has not been reported previously.

Recent studies in our laboratory have shown that microbial $\mathrm{Fe}$ - and $\mathrm{Mn}$-reducing activity is found frequently in production water samples from reservoirs. We speculate that iron and manganese oxides and hydroxides present in the petroleum

${ }^{*}$ Corresponding author. Phone: 616201 2381. Fax: 6162516361. E-mail: greene@science.canberra.edu.au. subsurface are conducive to the existence of metal-reducing microorganisms. This suggests that petroleum reservoirs represent a new source of metal-reducing microorganisms.

We describe in this paper the characteristics of a thermophilic manganese- and iron-reducing bacterium, designated strain $\mathrm{BMA}^{\mathrm{T}}$ ( $\mathrm{T}=$ type strain), which was isolated from the Beatrice oil reservoir (North Sea, United Kingdom).

\section{MATERIALS AND METHODS}

Source of bacterial strain. Bacterial strain $\mathrm{BMA}^{\mathrm{T}}$ was isolated from produced formation water collected from well A01(07) in the Beatrice oil field. The Beatrice oil field is located in the British sector of the North Sea near the coast of Scotland at a depth of $2,058 \mathrm{~m}$. The temperature of the reservoir ranges from 40 to $110^{\circ} \mathrm{C}$ across the field. The production water was anaerobic and had a leve of salinity $(\mathrm{NaCl})$ of $32 \mathrm{~g} /$ liter and a $\mathrm{pH}$ of 7.1 . The details of sample collection have been described elsewhere (12).

Media and culture conditions. A medium designated MR and based on Beatrice oil field reservoir chemistry was formulated to enrich for manganesereducing bacteria. MR medium was prepared anaerobically and contained (per liter of distilled water) $1 \mathrm{~g}$ of $\mathrm{NH}_{4} \mathrm{Cl}, 0.08 \mathrm{~g}$ of $\mathrm{K}_{2} \mathrm{HPO}_{4} \cdot 3 \mathrm{H}_{2} \mathrm{O}, 4.5 \mathrm{~g}$ of $\mathrm{MgCl}_{2} \cdot 6 \mathrm{H}_{2} \mathrm{O}, 0.375 \mathrm{~g}$ of $\mathrm{CaCl}_{2} \cdot 2 \mathrm{H}_{2} \mathrm{O}, 32 \mathrm{~g}$ of NaCl, $3.6 \mathrm{~g}$ of $\mathrm{NaHCO}_{3}, 2 \mathrm{~g}$ of yeast extract, and $1.3 \mathrm{~g}$ of $\mathrm{MnO}_{2}$. The $\mathrm{MnO}_{2}$ was prepared by the method of Lovley and Phillips (19). The $\mathrm{pH}$ of the medium was adjusted to 7.1 , and then the medium was boiled, cooled under a stream of $\mathrm{N}_{2}$, and dispensed into serum bottles under $\mathrm{N}_{2}-\mathrm{CO}_{2}(80: 20)$ to exclude oxygen; the bottles were capped with butyl rubber septa and autoclaved.

Isolation. Enrichment cultures were initiated by adding a 2-ml inoculum of production water to $20 \mathrm{ml}$ of MR medium and were incubated at $60^{\circ} \mathrm{C}$. Enrichment cultures that reduced $\mathrm{MnO}_{2}$ were subcultured a number of times. These cultures were then tested for growth on nitrate $(20 \mathrm{mM})$ as an alternative electron acceptor to $\mathrm{MnO}_{2}$. Pure cultures were obtained by the agar shake dilution method (14). The process involved serially diluting enrichment cultures in MR medium amended with $20 \mathrm{mM} \mathrm{NaNO}$ in place of $\mathrm{MnO}_{2}$ and fortified with agar $(2 \%)$ at $50^{\circ} \mathrm{C}$. The tubes then were cooled to solidify the agar and incubated at $60^{\circ} \mathrm{C}$. Several colonies were selected, grown in MR medium, and tested for the ability to reduce $\mathrm{MnO}_{2}$. The purity of cultures was checked microscopically.

Physiological studies. Strain $\mathrm{BMA}^{\mathrm{T}}$ was tested for its ability to use different terminal electron acceptors. Most electron acceptors were added from sterile stock solutions to MR medium lacking $\mathrm{MnO}_{2}$ at a final concentration of $20 \mathrm{mM}$; the only exceptions were $\mathrm{Mn}$ (IV) (final concentration, $15 \mathrm{mM}$ ), $\mathrm{Fe}$ (III) (15 mM), oxygen (atmospheric concentration), and elemental sulfur $(\sim 1 \mathrm{~g} /$ liter $)$.

The types of electron donors used by strain $\mathrm{BMA}^{\mathrm{T}}$ were determined in the presence of $\mathrm{MnO}_{2}$, amorphous ferric oxyhydroxide (18), or nitrate as an electron acceptor in triplicate. Most of the electron donors tested were added at a final 
concentration of $20 \mathrm{mM}$; the only exceptions were hydrogen $\left(80 \% \mathrm{H}_{2}-20 \% \mathrm{CO}_{2}\right.$ headspace), yeast extract $(0.2 \%)$, peptone $(0.2 \%)$, Casamino Acids $(0.2 \%)$, tryptone $(0.2 \%)$, and elemental sulfur $(\sim 1 \mathrm{~g} /$ liter $)$. All electron donors were added from sterile stock solutions to MR medium that contained $0.02 \%$ yeast extract instead of $0.2 \%$ yeast extract.

Experiments to determine temperature, salinity, and $\mathrm{pH}$ optima for growth were performed in MR medium and MR medium amended with $20 \mathrm{mM}$ nitrate instead of $\mathrm{MnO}_{2}$

The sensitivity of strain $\mathrm{BMA}^{\mathrm{T}}$ to antibiotics was assessed in MR medium. The antibiotics tested were penicillin $(150 \mu \mathrm{g} / \mathrm{ml})$, vancomycin $(150 \mu \mathrm{g} / \mathrm{ml})$, streptomycin $(150 \mu \mathrm{g} / \mathrm{ml})$, tetracycline $(100 \mu \mathrm{g} / \mathrm{ml})$, and cycloserine $(150 \mu \mathrm{g} / \mathrm{ml})$

All physiological studies were conducted either in water baths or in incubators without shaking at $60^{\circ} \mathrm{C}$ unless indicated otherwise.

Morphological characteristics. Gram reactions were determined by the method of Hucker (9) and the KOH lysis method of Buck (5). Cellular morphology was determined by phase-contrast microscopy. Electron microscopy was performed as described previously (2).

Analytical techniques. Manganese $\left(\mathrm{Mn}^{2+}\right)$ contents were determined by a modification of the method of Brewer and Spencer (4). Samples $(1 \mathrm{ml})$ were removed and treated with $0.25 \mathrm{M} \mathrm{H}_{2} \mathrm{SO}_{4}$ to remove $\mathrm{Mn}^{2+}$ adsorbed to $\mathrm{MnO}_{2}$ particles and to dissolve carbonate particulates. The resulting solution was filtered immediately, diluted to a volume of $100 \mathrm{ml}$, and then adjusted to $\mathrm{pH} 8$ to 9. A $4.6-\mathrm{ml}$ aliquot was mixed with $0.4 \mathrm{ml}$ of formaldoxime-ammonia reagent and the $A_{450}$ was determined within 2 to $30 \mathrm{~min}$. Control tests were performed to ensure that acid treatment did not dissolve the $\mathrm{MnO}_{2}$. The presence of Mn(IV) was assessed with a benzidine acetate reagent (10).

Reduced iron $\left(\mathrm{Fe}^{2+}\right)$ contents were determined by the ferrozine method (31) A $0.1-\mathrm{ml}$ sample was mixed with $3 \mathrm{ml}$ of ferrozine reagent, and after $1 \mathrm{~min}$ the $A_{562}$ was determined. Reduction of nitrate was assessed by using Merckoquant nitrate test strips.

Growth was assessed by visual turbidity and microscopic observations, and numbers of cells were determined by the most-probable-number technique (1)

DNA base composition. DNA was purified by the method of Marmur (21). The DNA $\mathrm{G}+\mathrm{C}$ content was determined by the thermal denaturation method (22)

$16 \mathrm{~S}$ rRNA analysis. PCR product of the 16S rRNA gene was sequenced directly with an automated model $\mathrm{ABI}$ sequencer by using a Prism dideoxy terminator cycle sequencing kit as recommended by the manufacturer (Applied Biosystems, Foster City, Calif.). The procedures used for phylogenetic analysis have been described previously $(26,27)$. The sequences used for phylogenetic comparison were obtained from the Ribosomal Database Project, version 5.0 (20), GenBank, and EMBL databases.

Nucleotide sequence accession number. The 16S rRNA sequence of strain $\mathrm{BMA}^{\mathrm{T}}$ has been deposited in the GenBank data library under accession number U75602

\section{RESULTS}

Enrichment and isolation. After 3 to 5 days of incubation at $60^{\circ} \mathrm{C}$, a positive enrichment culture was obtained, as shown by the reduction of black solid manganese to a white precipitate. This precipitate was identified as an $\mathrm{Mn}^{2+}$ complex, most likely manganese carbonate, by a benzidine acetate test. A pure culture designated strain $\mathrm{BMA}^{\mathrm{T}}$ was obtained from the enrichment culture by using the agar shake dilution technique.

Morphological characteristics. Strain $\mathrm{BMA}^{\mathrm{T}}$ was a nonspore-forming, gram-negative, rod-shaped bacterium. The cells were straight to bent rods that were about 0.3 to $0.5 \mu \mathrm{m}$ in diameter and 1 to $5 \mu \mathrm{m}$ long (Fig. 1). Electron micrographs of thin sections of strain $\mathrm{BMA}^{\mathrm{T}}$ revealed that the surface layer was separated from the cytoplasmic membrane by a periplasmic space. Colonies were 1 to $2 \mathrm{~mm}$ in diameter, orange-red pigmented, fairly flat, and round when they were grown in agar tubes with nitrate as an electron acceptor. Each strain BMA cell appeared to have a polar flagellum; however, motility was not evident in laboratory cultures.

Electron acceptors and donors. Strain $\mathrm{BMA}^{\mathrm{T}}$ was grown routinely by using $\mathrm{MnO}_{2}$ as the electron acceptor and yeast extract as the electron donor. Strain $\mathrm{BMA}^{\mathrm{T}}$ grew on three terminal electron acceptors, $\mathrm{Mn}(\mathrm{IV}), \mathrm{Fe}(\mathrm{III})$, and nitrate, but not on nitrite, sulfate, sulfite, thiosulfate, trimethylamine $\mathrm{N}$ oxide, fumarate, glycine, molybdate, and elemental sulfur. Both soluble Fe(III) citrate and insoluble Fe(III) oxide were reduced, although amorphous $\mathrm{Fe}$ (III) oxide was reduced more rapidly. The crystalline structure of $\mathrm{Fe}$ (III) influenced the reductive capacity of strain BMA $^{T}$. Poorly crystalline Fe(III)

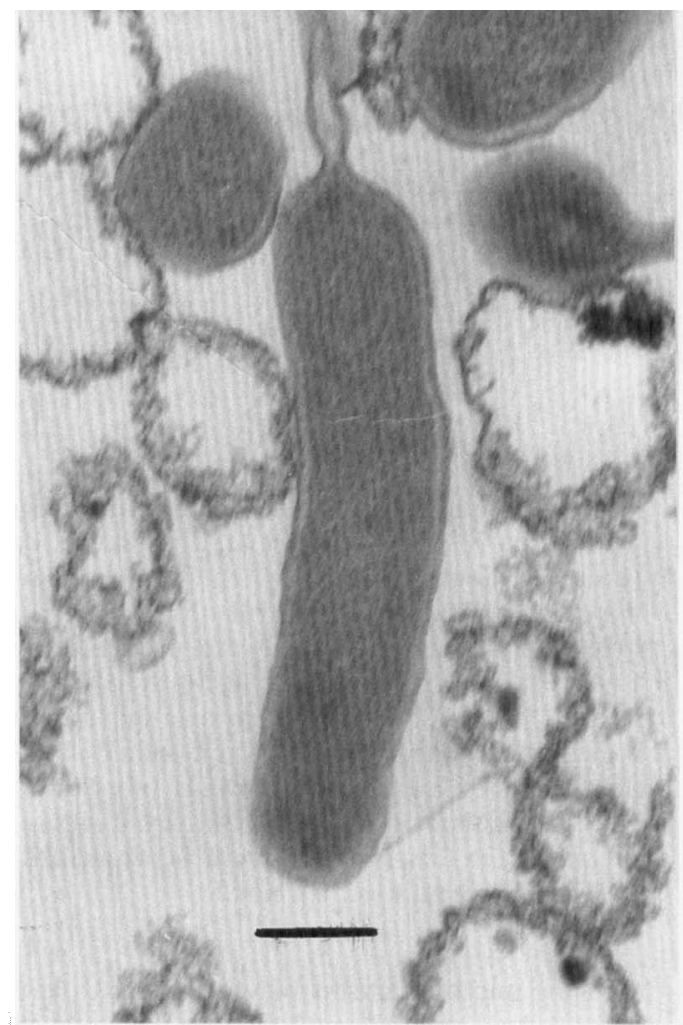

FIG. 1. Transmission electron micrograph of a thin section of strain $\mathrm{BMA}^{\mathrm{T}}$ Bar $=0.2 \mu \mathrm{m}$.

oxide was reduced by strain $\mathrm{BMA}^{\mathrm{T}}$, whereas the more crystalline $\mathrm{Fe}$ (III) oxide hematite was not. Strain $\mathrm{BMA}^{\mathrm{T}}$ was unable to grow with oxygen as a terminal electron acceptor at atmospheric or lower concentrations. Oxygen at atmospheric concentrations was toxic to strain BMA ${ }^{\mathrm{T}}$. However, strain $\mathrm{BMA}^{\mathrm{T}}$ was able to grow in the presence of small amounts of air (up to $3 \%$ [vol/vol]), provided that either $\mathrm{Mn}(\mathrm{IV}), \mathrm{Fe}(\mathrm{III})$, or nitrate and a suitable electron donor were added.

Strain $\mathrm{BMA}^{\mathrm{T}}$ grew best and reduced the electron acceptors most rapidly when yeast extract was provided as an electron donor. Other complex organic extracts, such as peptone, Casamino Acids, and tryptone, also supported growth and reduction of the electron acceptor. Strain $\mathrm{BMA}^{\mathrm{T}}$ also used acetate, malate, citrate, pyruvate, lactate, succinate, valerate, and hydrogen as electron donors. While strain $\mathrm{BMA}^{\mathrm{T}}$ was able to use extracts and some organic acids, it did not use carbohydrates, alcohols, and many other organic acids. Strain BMA was not able to use the following compounds as electron donors: elemental sulfur, glycine, formate, propionate, butyrate, isobutyrate, isovalerate, octanoate, oxalate, glutamate, fumarate, benzoate, salicylate, phenol, ethanol, propanol, butanol, pentanol, hexanol, octanol, nonanol, decanol, glycerol, 2,3butandiol, sorbitol, mannitol, glucose, lactose, sucrose, raffinose, rhamnose, fructose, maltose, xylose, mannose, stearate, palmitate, decanoate, and dodecanoate.

Manganese and iron reduction. A time course of $\mathrm{Mn}$ (IV) reduction and cell growth is shown in Fig. 2a. After an initial lag period, the onset of $\mathrm{Mn}^{2+}$ release corresponded to the most rapid increase in cell numbers. $\mathrm{Mn}^{2+}$ production continued through the stationary phase of growth and up to about $40 \mathrm{~h}$ of incubation; after that both $\mathrm{Mn}^{2+}$ levels and cell numbers declined. 

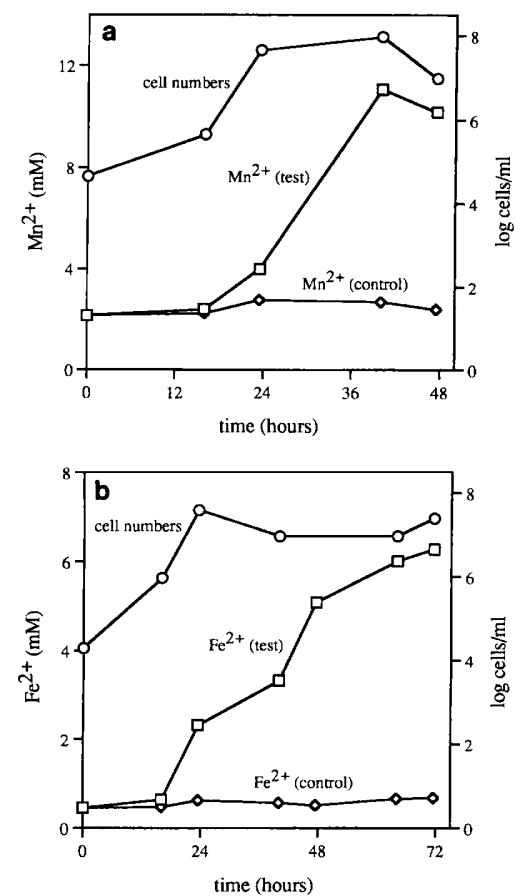

FIG. 2. (a) Time course of cell growth and Mn(IV) reduction by strain $\mathrm{BMA}^{\mathrm{T}}$. (b) Time course of cell growth and $\mathrm{Fe}(\mathrm{III})$ reduction by strain $\mathrm{BMA}^{\mathrm{T}}$.

The reduction of $\mathrm{Fe}(\mathrm{III})$ and the growth of cells over time are shown in Fig. $2 \mathrm{~b}$. The results were similar to the results obtained with the Mn-grown culture, although the initial $\mathrm{Fe}^{2+}$ release and the increases in cell numbers were more rapid. The $\mathrm{Fe}^{2+}$ levels continued to increase up to $72 \mathrm{~h}$, while the cell numbers remained fairly constant after $24 \mathrm{~h}$.

Reduction of $\mathrm{MnO}_{2}$ by strain $\mathrm{BMA}^{\mathrm{T}}$ yielded a whitish precipitate composed of the $\mathrm{Mn}$ (II) state. This precipitate was most likely an $\mathrm{Mn}$ carbonate or rhodocrosite compound formed due to the high carbonate and $\mathrm{CO}_{2}$ levels present in the medium. Reduction of amorphous Fe oxide resulted in the formation of a black solid high in the Fe(II) state. It is possible that this solid was magnetite or a carbonate compound, although this could not be confirmed without using structural analysis techniques, such as X-ray diffraction.

Growth conditions. Figure 3 shows the relationship between temperature and growth. Strain $\mathrm{BMA}^{\mathrm{T}}$ grew at temperatures between 50 and $65^{\circ} \mathrm{C}$, and the optimum temperature was $60^{\circ} \mathrm{C}$. Likewise, reduction of manganese occurred over the same

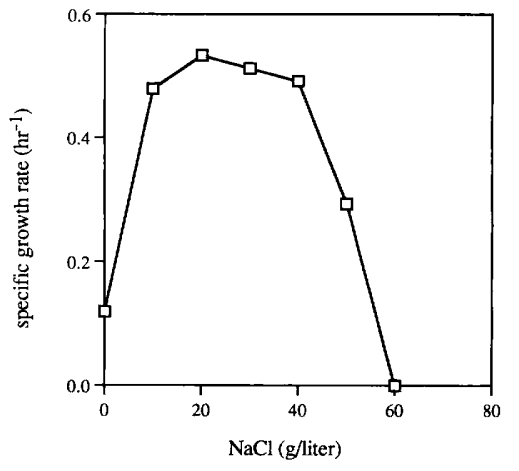

FIG. 4. Effect of salinity on the growth of strain $B M A^{T}$.

temperature range after 6 days of incubation and was most rapid at $60^{\circ} \mathrm{C}$.

Figure 4 shows the relationship between salinity $(\mathrm{NaCl})$ levels and growth. Growth occurred in the presence of $\mathrm{NaCl}$ concentrations ranging from 0 to $50 \mathrm{~g} /$ liter, and the optimum $\mathrm{NaCl}$ concentration was $20 \mathrm{~g} /$ liter. Manganese reduction occurred over the same salinity range as growth.

Figure 5 shows the relationship between $\mathrm{pH}$ and growth. Growth and reduction of manganese occurred at $\mathrm{pH}$ values ranging from 5 to 8 . Strain $\mathrm{BMA}^{\mathrm{T}}$ was slightly acidophilic, and the optimum $\mathrm{pH}$ for growth was 6.5 .

Antibiotic susceptibility. Growth of strain $\mathrm{BMA}^{\mathrm{T}}$ was inhibited by penicillin, vancomycin, streptomycin, and cycloserine. Growth and manganese reduction occurred in the presence of tetracycline.

DNA base composition. Strain $\mathrm{BMA}^{\mathrm{T}}$ had a $\mathrm{G}+\mathrm{C}$ content of $34 \mathrm{~mol} \%$.

Phylogenetic analysis. An almost complete sequence (1,526 bases) of strain BMA $^{\mathrm{T}} 16 \mathrm{~S}$ rRNA was obtained and aligned with various sequences from representatives of the domain Bacteria. Figure 6 shows a dendrogram generated from a Jukes-Cantor evolutionary distance matrix, with the phylogenetic position of strain $\mathrm{BMA}^{\mathrm{T}}$ indicated. The organism most closely related to strain $\mathrm{BMA}^{\mathrm{T}}$ is Flexistipes sinusarabici (level of similarity, $88 \%$ ). The level of similarity of the recently described organism G. ferrireducens (6) was $87 \%$.

\section{DISCUSSION}

The prevailing physicochemical conditions, particularly the high temperatures and high levels of salinity, in many petroleum reservoirs mean that novel microorganisms such as strain

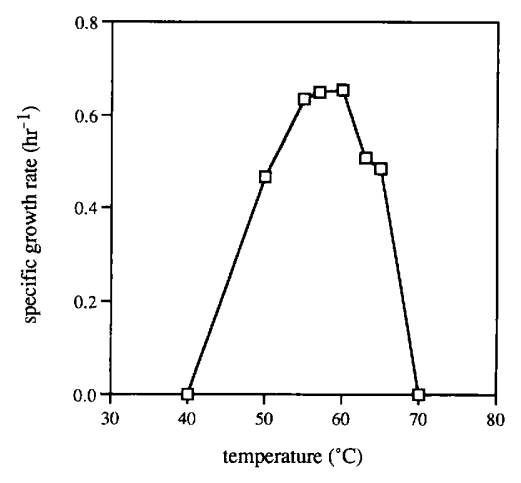

FIG. 3. Effect of temperature on the growth of strain $\mathrm{BMA}^{\mathrm{T}}$.

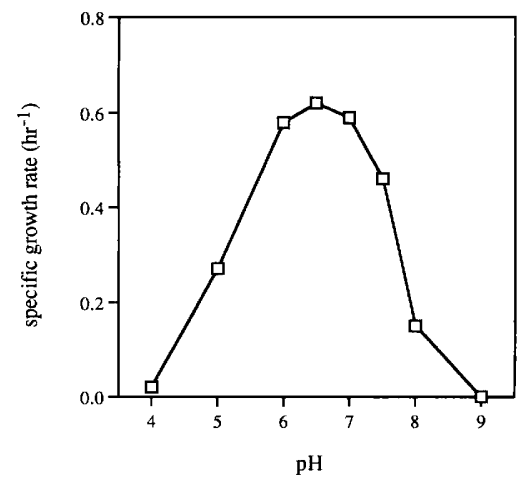

FIG. 5. Effect of $\mathrm{pH}$ on the growth of strain $\mathrm{BMA}^{\mathrm{T}}$ 


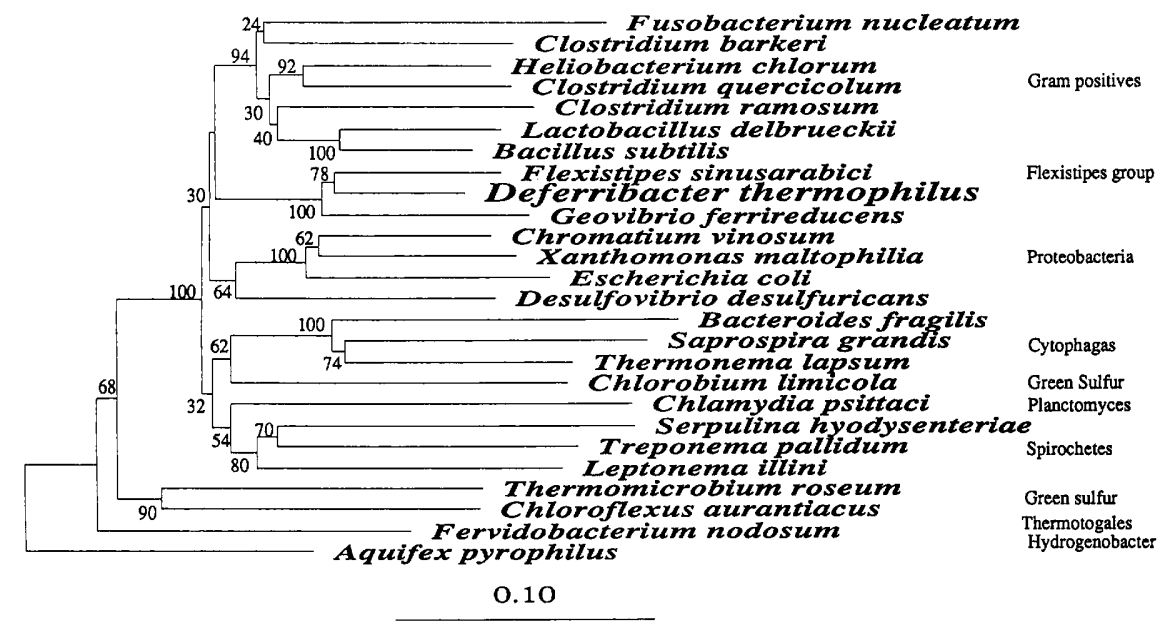

FIG. 6. Dendrogram showing the phylogenetic position of strain $\mathrm{BMA}^{\mathrm{T}}$. Most of the sequences used in the analysis were obtained from the Ribosomal Database Project, version 5.0 (20); the only exception was the sequence of $G$. ferireducens ATCC 51996 (6), which was obtained from the EMBL (accession no. X95744).

$\mathrm{BMA}^{\mathrm{T}}$ are likely to be present. Strain $\mathrm{BMA}^{\mathrm{T}}$ is the first thermophilic Mn- and Fe-reducing isolate obtained from a petroleum reservoir.

Iron and manganese oxides and hydroxides are common in the subsurface environment and can be present in oil-bearing rock (24). The presence of these compounds provides an ecological niche for iron- and manganese-reducing microorganisms. We postulate that metal reduction has evolved as a mechanism by which many respiring microorganisms persist in the subsurface environment.

Strain $\mathrm{BMA}^{\mathrm{T}}$ was able to use acetate and hydrogen as electron donors. Most other metal reducers use acetate or hydrogen. This is significant because acetate and hydrogen are common products of fermentation and fermentative microorganisms are common inhabitants of petroleum reservoirs, including the Beatrice field (12). The temperature and salinity optima of strain $\mathrm{BMA}^{\mathrm{T}}, 60^{\circ} \mathrm{C}$ and $2 \% \mathrm{NaCl}$, respectively, are consistent with the in situ conditions in the Beatrice petroleum reservoir. It is probable that strain $\mathrm{BMA}^{\mathrm{T}}$ actively uses acetate and/or hydrogen in situ.

The analysis of $16 \mathrm{~S}$ rRNA sequences showed that $G$. ferrireducens is the only previously described metal-reducing microorganism related to strain $\mathrm{BMA}^{\mathrm{T}}$. Many of the previously described $\mathrm{Fe}$ and $\mathrm{Mn}$ reducers are mesophilic organisms belonging to the delta subdivision of the Proteobacteria (15). Other $\mathrm{Fe}$ and $\mathrm{Mn}$ reducers are found in the gamma subdivision of the Proteobacteria. The thermophile $B$. infernus is not related to other metal-reducing microorganisms and is placed in the Bacillus-Lactobacillus-Streptococcus subdivision of the grampositive phylum. This shows the genetic diversity of metal reducers and supports the claim of Lonergan et al. (15) that metal reduction may be a characteristic that is widespread in the domain Bacteria. Reduction of $\mathrm{Fe}(\mathrm{III})$ or $\mathrm{Mn}(\mathrm{IV})$ is not tested routinely in physiological characterization studies, so it is possible that many microorganisms, particularly those isolated from the subsurface, have the capacity to reduce metals.

Phylogenetically, the closest known relatives of strain $\mathrm{BMA}^{\mathrm{T}}$ are $F$. sinusarabici, an organism isolated from hot brine waters of the Red Sea (11), and $G$. ferrireducens, an organism isolated from surface sediment in a hydrocarbon-contaminated ditch (6). Table 1 shows a comparison of some phenotypic characteristics of these organisms. The three bacteria share few characteristics. Only strain $\mathrm{BMA}^{\mathbf{T}}$ and $F$. sinusarabici appear to be similar morphologically. Strain $\mathrm{BMA}^{\mathrm{T}}$ and $G$. ferrireducens respire anaerobically, while $F$. sinusarabici has fermentative metabolism. Like $F$. sinusarabici, strain $\mathrm{BMA}^{\mathrm{T}}$ is sensitive to penicillin, vancomycin, and streptomycin and is resistant to tetracycline. Strain $\mathrm{BMA}^{\mathrm{T}}$ is thermophilic, while $F$. sinusarabici is only moderately thermophilic and $G$. ferrireducens is mesophilic. On the basis of phylogenetic and phenotypic traits, we propose that strain $\mathrm{BMA}^{\mathrm{T}}$ should be described as a member of a novel species of a new genus.

Description of Deferribacter gen. nov. Deferribacter (De.fer.ri. bac'ter. L. pref. de, from; L. n. ferrum, iron; Gr. hyp. masc. n. bacter, rod; M. L. masc. n. Deferribacter, rod that reduces iron). Cells are gram negative and rod shaped and can vary in length. No spores are produced, and motility is not evident. Growth occurs under anaerobic conditions with iron(III), manganese(IV), and nitrate as electron acceptors. Complex organic extracts, such as yeast extract, and numerous organic acids can be used as electron donors. No fermentation occurs. Phylogenetically, the genus groups with the general cluster of eubacteria.

TABLE 1. Comparison of some characteristics of strain $\mathrm{BMA}^{\mathrm{T}}$, $F$. sinusarabici, and G. ferrireducens

\begin{tabular}{|c|c|c|c|}
\hline Characteristic & Strain $\mathrm{BMA}^{\mathrm{T}}$ & F. sinusarabici ${ }^{a}$ & G. ferireducens $s^{b}$ \\
\hline Gram reaction & Negative & Negative & Negative \\
\hline Morphology & $\begin{array}{l}\text { Straight to } \\
\text { bent rods }\end{array}$ & $\begin{array}{l}\text { Straight to } \\
\text { bent rods }\end{array}$ & Vibrio shaped \\
\hline Metabolism & Respiratory & Fermentative & Respiratory \\
\hline Optimum temp $\left({ }^{\circ} \mathrm{C}\right)$ & 60 & $45-50$ & 35 \\
\hline Salinity range $(\%, \mathrm{wt} / \mathrm{vol})$ & $0-6$ & $3-18$ & $0-2$ \\
\hline $\mathrm{G}+\mathrm{C}$ content $(\mathrm{mol} \%)$ & 34 & 39 & 43 \\
\hline Reduction of Mn(IV) & + & - & - \\
\hline Reduction of $\mathrm{Fe}$ (III) & + & - & + \\
\hline \multicolumn{4}{|l|}{ Antibiotic sensitivity } \\
\hline Vancomycin & + & + & $\mathrm{NT}^{c}$ \\
\hline Penicillin & + & + & NT \\
\hline Streptomycin & + & + & NT \\
\hline Cycloserine & + & + & NT \\
\hline Tetracycline & - & - & NT \\
\hline
\end{tabular}

${ }^{a}$ Data from reference 11

${ }^{b}$ Data from reference 6 .

${ }^{c} \mathrm{NT}$, not tested. 
Description of Deferribacter thermophilus sp. nov. Deferribacter thermophilus (ther.mo' phil.us. Gr. adj. thermus, warm, hot; Gr. adj. philos, loving; M. L. masc. adj. thermophilus, heat loving). Cells range from about 0.3 to $0.5 \mu \mathrm{m}$ wide and from 1 to $5 \mu \mathrm{m}$ long. Growth occurs at temperatures between 50 and $65^{\circ} \mathrm{C}$ (optimum temperature, $60^{\circ} \mathrm{C}$ ), in the presence of $\mathrm{NaCl}$ concentrations ranging from 0 to $50 \mathrm{~g} /$ liter (optimum $\mathrm{NaCl}$ concentration, $20 \mathrm{~g} /$ liter), and at $\mathrm{pH} 5$ to 8 (optimum $\mathrm{pH}, 6.5$ ). Hydrogen, acetate, malate, citrate, pyruvate, lactate, succinate, and valerate are used as electron donors. The DNA base composition is $34 \mathrm{~mol} \% \mathrm{G}+\mathrm{C}$. Sensitive to penicillin, vancomycin, streptomycin, and cycloserine and resistant to tetracycline.

The type strain is Deferribacter thermophilus BMA, which was obtained from produced water from the Beatrice petroleum reservoir. This reservoir is a high-temperature, seawaterflooded reservoir and is located in the British sector of the North Sea. Strain BMA $^{\mathrm{T}}$ has been deposited in the Australian Collection of Microorganisms, University of Queensland, Brisbane, Australia as strain ACM $5093^{\mathrm{T}}$.

\section{ACKNOWLEDGMENTS}

This research was funded by Lang Oil Technology Berhad, Malaysia. We thank Kathryn Russell and Elaine Wyatt for technical assistance. We appreciated the helpful discussions which we had with our colleagues Gino Grassia and Gavin Rees during this work. We also thank Live Oil Services NV and BP Exploration (United Kingdom) for providing production water samples.

\section{REFERENCES}

1. American Public Health Association. 1992. Standard methods for the examination of water and wastewater. American Public Health Association, Washington, D.C.

2. Andrews, C., and B. K. C. Patel. 1996. Fervidobacterium gondwanense sp. nov., a new thermophilic anaerobic bacterium isolated from nonvolcanically heated geothermal waters of the Great Artesian Basin of Australia. Int. J. Syst. Bacteriol. 46:265-269.

3. Boone, D. R., Y. Liu, Z.-J. Zhao, D. L. Balkwill, G. R. Drake, T. O. Stevens, and H. C. Aldrich. 1995. Bacillus infermus sp. nov., an $\mathrm{Fe}(\mathrm{III})-$ and $\mathrm{Mn}(\mathrm{IV})$ reducing anaerobe from the deep terrestrial subsurface. Int. J. Syst. Bacteriol. 45:441-448.

4. Brewer, P. G., and D. W. Spencer. 1971. Colorimetric determination of manganese in anoxic waters. Limnol. Oceanogr. 16:107-112.

5. Buck, J. D. 1982. Nonstaining (KOH) method for determination of Gram reactions of marine bacteria. Appl. Environ. Microbiol. 44:992-993.

6. Caccavo, F., Jr., J. D. Coates, R. A. Rossello-Mora, W. Ludwig, K. H. Schleifer, D. R. Lovley, and M. J. McInerney. 1996. Geovibrio ferrireducens, a phylogenetically distinct dissimilatory $\mathrm{Fe}$ (III)-reducing bacterium. Arch. Microbiol. 165:370-376.

7. Cayol, J.-L., B. Ollivier, B. K. C. Patel, G. Ravot, M. Magot, E. Ageron, P. A. D. Grimont, and J.-L. Garcia. 1995. Description of Thermoanaerobacter brockii subsp. lactiethylicus subsp. nov., isolated from a deep subsurface French oil well, a proposal to reclassify Thermoanaerobacter finnii as Thermoanaerobacter brockii subsp. finnii comb. nov., and an emended description of Thermoanaerobacter brockii. Int. J. Syst. Bacteriol. 45:783-789.

8. Davydova-Charakhch'yan, I. A., V. G. Kuznetsova, L. L. Mityushina, and S. S. Belayaev. 1993. Methane-forming bacilli from oil fields of Tartaria and Western Siberia. Microbiology (Engl. Transl. Mikrobiologiya) 61:202-207.

9. Doetsch, R. N. 1981. Determinative methods of light microscopy, p. 21-33. In P. Gerhardt, R. G. E. Murray, R. N. Costilow, E. W. Nester, W. A. Wood, N. R. Krieg, and G. B. Phillips (ed.), Manual of methods for general bacteriology. American Society for Microbiology, Washington, D.C

10. Feigl, F. 1958. Spot tests in inorganic analysis. Elsevier, New York, N.Y.
11. Fiala, G., C. R. Woese, T. A. Langworthy, and K. O. Stetter. 1990. Flexistipes sinusarabici, a novel genus and species of eubacteria occurring in the Atlantis II deep brines of the Red Sea. Arch. Microbiol. 154:120-126.

12. Grassia, G. S., K. M. McLean, P. Glenat, J. Bauld, and A. J. Sheehy. 1996 A systematic survey for thermophilic fermentative bacteria and archaea in high temperature petroleum reservoirs. FEMS Microbiol. Ecol. 21:47-58.

13. Jeanthon, C., A.-L. Reysenbach, S. L'Haridon, A. Gambacorta, N. R. Pace, P Glenat, and D. Prieur. 1995. Thermotoga subterranea sp. nov., a new thermophilic bacterium isolated from a continental oil reservoir. Arch. Microbiol. 164:91-97.

14. Ljungdahl, L. G., and J. Wiegel. 1986. Working with anaerobic bacteria, p 84-96. In A. L. Demain and N. A. Solomon (ed.), Manual of industria microbiology. American Society for Microbiology, Washington, D.C.

15. Lonergan, D. J., H. L. Jenter, J. D. Coates, E. J. P. Phillips, T. M. Schmidt, and D. R. Lovley. 1996. Phylogenetic analysis of dissimilatory Fe(III)-reducing bacteria. J. Bacteriol. 178:2402-2408.

16. Lovley, D. R. 1991. Dissimilatory Fe(III) and Mn(IV) reduction. Microbiol. Rev. 55:259-287.

17. Lovley, D. R. 1993. Dissimilatory metal reduction. Annu. Rev. Microbiol. 47: 263-290.

18. Lovley, D. R., and E. J. P. Phillips. 1986. Organic matter mineralization with reduction of ferric iron in anaerobic sediments. Appl. Environ. Microbiol. 52:683-689.

19. Lovley, D. R., and E. J. P. Phillips. 1988. Novel mode of microbial energy metabolism: organic carbon oxidation coupled to dissimilatory reduction of iron or manganese. Appl. Environ. Microbiol. 54:1472-1480.

20. Maidak, B. L., G. J. Olsen, N. Larsen, R. Overbeek, M. J. McCaughey, and C. R. Woese. 1996. The Ribosomal Database Project (RDP). Nucleic Acids Res. 24:82-85.

21. Marmur, M. 1961. A procedure for the isolation of deoxyribonucleic acid from microorganisms. J. Mol. Biol. 3:208-218.

22. Marmur, M., and P. Doty. 1962. Determination of the base composition of deoxyribonucleic acid from its thermal denaturation temperature. J. Mol. Biol. 5:109-118.

23. Myers, C. R., and K. H. Nealson. 1988. Bacterial manganese reduction and growth with manganese oxide as the sole electron acceptor. Science $\mathbf{2 4 0}$ 1319-1321.

24. Nazina, T. N., A. E. Ivanova, O. V. Golubeva, R. R. Ibatullin, S. S. Belyaev, and M. V. Ivanov. 1995. Occurrence of sulfate- and iron-reducing bacteria in stratal waters of the Romashkinskoe oil field. Microbiology (Engl. Transl. Mikrobiologiya) 64:203-208

25. Nealson, K. H., and D. Saffarini. 1994. Iron and manganese in anaerobic respiration: environmental significance, physiology, and regulation. Annu. Rev. Microbiol. 48:311-343.

26. Ravot, G., M. Magot, M.-L. Fardeau, B. K. C. Patel, G. Prensier, A. Egan, J.-L. Garcia, and B. Ollivier. 1995. Thermotoga elfii sp. nov., a novel thermophilic bacterium from an African oil-producing well. Int. J. Syst. Bacteriol. 45:308-314.

27. Rees, G. N., G. S. Grassia, A. J. Sheehy, P. P. Dwivedi, and B. K. C. Patel. 1995. Desulfacinum infermum gen. nov., sp. nov., a thermophilic sulfatereducing bacterium from a petroleum reservoir. Int. J. Syst. Bacteriol. 45 $85-89$.

28. Rossello-Mora, R. A., F. Caccavo, Jr., K. Osterlehner, N. Springer, S. Spring, D. Schüler, W. Ludwig, R. Amann, M. Vanncanney, and K. H. Schleifer. 1994. Isolation and taxonomic characterisation of a halotolerant, Schleifer. 1994. Isolation and taxonomic characterisation of a halotoleran
facultative iron-reducing bacterium. Syst. Appl. Microbiol. 17:569-573.

29. Semple, K. M., and D. W. S. Westlake. 1987. Characterization of ironreducing Alteromonas putrefaciens strains from oil field fluids. Can. J. Microbiol. 33:366-371.

30. Slobodkin, A. I., V. A. Eroshchev-Shak, N. A. Kostrikina, V. Y. Lavrushin L. G. Dainyak, and G. A. Zavarzin. 1995. Magnetite formation by thermophilic anaerobic microorganisms. Dokl. Biol. Sci. (Engl. Transl. Dokl. Akad. Nauk SSSR) 345:663-666.

31. Sorensen, J. 1982. Reduction of ferric iron in anaerobic, marine sediment and interaction with reduction of nitrate and sulfate. Appl. Environ. Microbiol. 43:1472-1480.

32. Stetter, K. O., R. Huber, E. Blochl, M. Kurr, R. D. Eden, M. Fielder, H Cash, and I. Vance. 1993. Hyperthermophilic archaea are thriving in deep North Sea and Alaskan oil reservoirs. Nature 365:743-745. 